\title{
Assessment of gender differentials in economic and technical efficiency of poultry egg, a case study in Lagos State, Nigeria.
}

\section{Evaluación de las diferencias de género en la eficiencia económica y técnica de los huevos de aves de corral, un estudio de caso en el estado de Lagos, Nigeria.}

Hafis O. Odunlami, ${ }^{1}$; Peter Adebola Okuneye, ${ }^{1}$; Adebayo Musediku Shittu ${ }^{1}$; Ajani R. Sanusi, ${ }^{1}$; Isa Olalekan Elegbede $^{2}$; Fatima Kies ${ }^{3}$

1- Department of Agricultural Economics and Farm Management, Federal University of Agriculture, Abeokuta, Ogun State, Nigeria.

2- Department of Environmental Planning, Brandenburg University of Technology, Cottbus-Senftenberg, Germany. Email: isaelegbede@gmail.com

3- Department of Earth and Environmental Sciences, Università Degli Studi di Milano-Bicocca Milano, Lombardy, Italy

Abstract

Gender has been seen as an important factor in the distribution and utilization of productive resources worldwide. In the agricultural sector, gender differential could influence the sourcing and efficient utilization of factors of production, particularly in the livestock sub-sector of the economy. This study assessed the gender differentials in economic and technical efficiency of poultry eggs production in Lagos State, Nigeria. Multistage sampling technique was used to select respondent poultry farmers. The first and second stages were the purposive selection of five Local Government Areas (LGAs) reputed for poultry production and farm settlements in the state. The third stage involved a simple random sampling of 150 poultry farms consisting of 75 farms each managed by a male and a female Stochastic Frontier Analysis (SFA). The SFA revealed that for male management of poultry egg farms, labour input $(p<0.01)$ and cost of medications $(p<0.05)$ increased the poultry egg output. On the other hand, for female management, stock of birds $(p<0.01)$, labor input $(p<0.01)$ and feed cost $(p<0.01)$ were the factors that increased poultry eggs output. The inefficiency model revealed that male farmers were more technically efficient $(p<0.01)$ than female counterparts. Female managed poultry farms had less productivity (0.90) compared to males (1.22). However, $88.1 \%$ of male farms compared to $86.7 \%$ of female farms had economic efficiency ratios between 0.29 and 0.79 . The study concluded that gender had impact on poultry farmers' efficiency in the study area. The study therefore recommended that training should be organised for female managed farms while male managed farms should utilize less of cost intensive capital input.

Keywords: Agricultural resource, poultry production, sustainable livestock, multistage sampling technique, Stochastic Frontier Analysis (SFA).

Resumen

El género ha sido visto como un factor importante en la distribución y utilización de los recursos productivos en todo el mundo. En el sector agrícola, la diferencia de género puede influir en la compra de componentes y eficiente utilización de los factores de producción, en particular en el subsector ganadero de la economía. Este estudio evaluó las diferencias de género en la eficiencia económica y técnica de la producción de huevos de aves de corral en el estado de Lagos, Nigeria. técnica de muestreo de múltiples etapas se utilizó para seleccionar los avicultores demandado. La primera y segunda etapas fueron la selección intencional de cinco áreas del gobierno local ( $A G L)$, famosas por la producción de aves de corral y los asentamientos agrícolas en el estado. La tercera etapa consistió en una muestra aleatoria simple de 
150 granjas avícolas que consiste en 75 granjas cada gestionados por un macho y una hembra de análisis de frontera estocástica (SFA). La SFA reveló que para el manejo de los machos de las granjas de aves de huevo, el insumo de trabajo $(p<0,01)$ y el costo de los medicamentos $(p<0,05)$ incrementó la producción de aves de corral huevo. Por otro lado, para la gestión de la hembra, las acciones de las aves $(p<0,01)$, el factor trabajo $(p<0,01)$ y el costo del alimento $(p<0,01)$ fueron los factores que incrementaron la producción de huevos de aves de corral. El modelo de ineficiencia reveló que los agricultores varones eran más técnicamente eficiente $(p<0,01)$ que sus contrapartes femeninas. granjas avícolas que gestiona femeninos tenían una menor productividad $(0,90)$ que en hombres $(1,22)$. Sin embargo, el $88,1 \%$ de las explotaciones varones en comparación con el $86,7 \%$ de las explotaciones hembra tenía índices de eficiencia económica entre 0,29 y 0,79. El estudio concluyó que el género tuvo impacto en la eficiencia de aves de corral de los agricultores en el área de estudio. Por lo tanto, el estudio recomienda que la formación debe organizarse para las explotaciones gestionadas femeninos mientras que las granjas administradas varones deben utilizar menos de la entrada de capital intensivo de costes.

Palabras clave: recursos agrícolas, producción de aves de corral, animales de granja sostenible, de muestreo de multietapas, análisis estocástico de frontera (SFA)

Introduction

Prior to oil discovery, agriculture was the major sector contributing to the Nigeria economy.Nigeria'smain source of foreign exchange earnings was agriculture as at 1960s which accounted for over $60 \%$ of its GrossDomestic Product (GDP).During this period, Nigerian economy was known as agricultural economy due to the fact that agriculture carries the largest percentage of the growth of the overall economy (Tijani, et al., 2015).

The most important thing that can happen to any country is agriculture opined that "The happiness of a nation is compared to a tree, its roots is farming while industry and commerce are its branches and leaves. If the root is uprooted, the branches will seize to live and the leaves will start to drop". That's how important agriculture is to any nation (Paddy, 2001).

Agriculture remains the single largest contributor to the Gross Domestic Product (GDP), industrialization and employment. The main value of Agriculture in the development and growth of the Nigerian economy is indicated in its contribution to industrialization, food security and the relationship with employment, income, market opportunities for industries and poverty reduction. Although, Agricultural sector is yet to attract the right kind of attention and quantum of investments that will make it to realize its potentials economically. Agricultural development and growth is vital to increase food supplies and improve the nutritional status of the people of Africa. This is factually correct for Africa whereby food production per person actually fell over the last 20 years (Deller, 2014; Da Silva, 2009).

In Nigeria, agriculture caters for the livelihood of over $70 \%$ of the population, with capability to provide raw materials for agro-allied industries. The Gross Domestic Product (GDP) contribution of agriculture is about $40 \%$ and is an effective sector of foreign exchange earnings. Also a major economic segment in the rural and sub urban region with majority of the country's population (Chukwuji et al., 2006; Odetola, \& Etumnu, 2013).

Poultry production is a sub-sector of agricultural industry in Nigeria. Apart from the fact that poultry provide protein, it is also a source of vitamins and lipids of high value to man. Animal protein is necessary in human nutrition due to its biological importance. In achieving high level of animal protein, Nigeria government have been in pursuit of programs at community, state and national levels to increase the mass production of livestock products and to enable the attainment of Food and Agriculture Organization (FAO) (Bamiro, et. al, 2006; Bamiro, et al 2013).

One of the developmental challenges confronting most developing countries has to do with the lack of ability to adequately cater for their ever-increasing population with the right proportion of protein and calories (Apantaku, 2006). In Nigeria, the production of food is yet to meet the rate at which population increases. The rate of increased food production of $2.5 \%$ per annum does not meet up with the annual population growth of $2.8 \%$. The apparent disparity between the rate of food production and food demand in Nigeria has resulted to a food demand supply gap thus leading to a wide gap between 
total food requirement and domestic food, an increasing resort to food importation, high rates of increase in food prices, leading to widespread of hunger and malnutrition in the country (Bamiro, et al 2013).

Poultry refers to birds that are of economic value to man which produces fibre, egg and meat. Egg production has to do with the use of viable layer birds, raised for the purpose of egg production (Mukhtar, 2012). Animal protein is essential in human nutrition because of its biological significance. Poultry and poultry products such as poultry meat and eggs are important food items for improving nutritional and health status particularly of children, pregnant women and weak persons (Olaniyiet al 2008).

There has been a great disparity between men and women in their involvements in farm activities and the making of farm decisions (Rahman et al., 2007). In most cases, women are limited in their involvement in farm decisions compared to men (Rahman and Alamu 2003). Despite their considerable involvement and contribution, women's role in livestock production has often been underestimated or, ignored (IFAD 2007). Despite the significant role of female farmers, their level of productivity is reduced due to the fact that agricultural technology has been manufactured on the assumption that farm managers are men. This assumption leads to several other constraints as regards the success of female farmer's conditions: inability of agricultural extension workers to contact them; inaccessibility to credit inputs; inability to access important technological information; limited incentive to increase productivity (Saito and Spurling 2000). According to Okoh, et al . (2010) most policies designed at making agro-technological inputs available to female farmers in Nigeria were in actual fact directed towards men. This paper aim to engage in an assessment of gender differentials in economic and technical efficiency of poultry (egg) farm in Lagos State, Nigeria. This paper presents useful information to stakeholders on the status of females in poultry agriculture.

\section{Material and Methods}

Study area : the creation of Lagos State was dated back to May 27, 1967 through State (Creation and Transitional provisions) Decree No. 14 of 1967, which reorganized the Federation of Nigeria into 12 States. The Federal Government governed the Lagos Municipality through the Federal Ministry of Lagos Affairs as the authority of the region, while City of Lagos was controlled by the Lagos City Council (LCC), the Western Region was likewise in charge of the administration of areas such as Badagry, Epe, Ikorodu, Mushin, Agege, Ikeja (Akanle \& Olutayo, 2011).

For more than 10 years, Lagos has been the center of Nigeria's social and economic development, currently having the population of over 20 million, which according to projections by 2025 will have risen to 30 million (Ogungbeni, et al., 2013).Provision of housing, food, healthcare, jobs and social amenities to its occupants are some of the challenges facing Lagos state.

From the inception, Lagos has been experiencing an expansion on the mainland west of the lagoon and the continuous aggregation of built-up urban communities, such as Agege and Ikeja, now extends to more than $40 \mathrm{~km}$ north-west of Lagos Island. Some suburbs include Ikorodu, Epe and Badagry, and of recent there have been an additional creation of local councils, making the total number of Local Governments Area Development Councils in Lagos to fifty-seven (57).

Table 1. Number of poultry farms selected by LGA and the communities.

\begin{tabular}{lll}
\hline LGAs & Community/VillagesNumber of Farms & 30 \\
\hline Epe & Isala,Araga,Odo-Obara,Temu,Odomola, & 30 \\
& Igboye, Eredo, Odo-irangansi, Poka & 30 \\
Badagry & Ikoga & 30 \\
Alimosho & Ayobi-Ipaja,Egan Alafia & 30 \\
Ojo & Ayedota farm settlement & 30 \\
Ikorodu & Agunfoye,Sawmill,Imota,Ijede,Odongunyan,Igbalu,Igbogbo & 150 \\
Total & & \\
\hline
\end{tabular}

Source: Field Survey, 2013 
Sampling technique and sample size : the study was based on data collected in a cross sectional survey that covered 150 poultry farms drawn by multi stage random sampling technique from Lagos State (Table 1). Based on information obtained from Lagos State Agricultural Development Authority (LASADA), five Local Government Areas (LGAs) that are mainly poultry producing areas in Lagos State were purposively selected at stage 1 of the sampling process. These are (Epe, Alimosho, Badagry, Ojo and Ikorodu). Given that no sampling frame of the poultry farms in each LGA was available, a purposive selection of 30 poultry (egg) farms from each of the LGA was undertaken using snowball sampling.

Method of Data Collection : primary data was mainly employed for this study. Information about the respondents was collected through the use of questionnaire. Data were collected on socio-economic characteristics such as age, gender, marital status, educational status, credit access and household variables.

Method of Data Analysis: the data collected were analyzed using descriptive statistics and multiple regression analysis

Descriptive statistics: descriptive techniques including the use of frequency distribution and compilation of mean and standard error were used to analyze and describe socio-economic characteristics of both male and female poultry farmers in the study area etc.

Stochastic Production frontier Estimation : the stochastic frontier analysis of Battase and Coelli $(1992,1995)$ as commonly applied by $\operatorname{Anos}(2006)$ and Adepoju(2008) shall be employed in estimating the technicaland overall economic efficiency in this study.

(a) Production Frontier

$\operatorname{LnQ}=\beta_{0}+\Sigma \beta_{i} \ln X_{i}+(V i-U i)$

Where:

$Q=$ is the output which represents the total number of eggs

$\mathrm{Xi}=$ vector of inputs

$\beta o=$ intercept

$\beta \mathbf{i}=$ vector of parameters to be estimated

Dependent variables:

- Qistheoutputwhichrepresentsthetotalnumberofeggs

Independent variables:

- $\quad \mathrm{X}_{1}=$ Farm size (number of birds)

- $\quad X_{2}=$ Labour input (Man days)

- $X_{3}=$ Total feed supply (kg)

- $\mathrm{X}_{4}=$ Cost of drug and medication (

(b) Inefficiency equation

Some farmers' characteristics will be incorporated into the frontier functions as it is believed that they have direct influence on efficiency. The inefficiency function is specified as:

$R=b_{0}+b_{1} z_{1}+b_{2} z_{2}+b_{3} z_{3}+b_{4} z_{4}+b_{5} z_{5}+b_{6} z_{6}+e$

Where:

$\mathrm{R}=$ Inefficiency

$Z_{1}=$ Years of experience

$\mathrm{Z}_{2}$ = Educational level

$Z_{3}=$ Marital status (dummy variables: 1 if married, 0 otherwise)

$Z_{4}=$ Access to extension service

$Z_{5}=$ Access to credit

$Z_{6}=$ Sex (dummy variables 1 if male, 0 otherwise)

Results and Discussion 
Socio-economic Characteristics : the distribution of age, sex, marital status and educational level of the poultry egg farmers is presented in Table 2 . The findings showed that $62.7 \%$ and $73.3 \%$ of male and female poultry egg farmers are aged below 50 years. This implies that majority of the farmers are in their active age and are therefore expected to influence the efficiency of the farm units sampled. The findings further showed that majority $94.7 \%$ of male farmers and $85.3 \%$ of female farmers were married, While 4.0\% and $9.3 \%$ are single for male and female farmers respectively. The respondents that are widowed for male and female farmers account for $1.3 \%$ and $5.3 \%$ respectively. The marital status of a poultry egg farmer has implication on the household size and subsequently on the availability of family labour to assist on the farm. Results from the study also revealed that majority $80.5 \%$ of male farmers have postsecondary education while $73.3 \%$ of female farmers also have post-secondary education. The result of the survey further showed that $80 \%$ of male and $85.3 \%$ female farmers respectively had below $9 y e a r s$ experience while $16.0 \%$ of male and $14.7 \%$ of female farmers had between 10 and 19 years of experience in poultry farming. Table 3 shows the years of experience, religion, ethnicity and household size of poultry egg farmers. The years of experience of the poultry egg farmers is supposed to have a positive influence on the production efficiency of the poultry farm unit ceteris paribus. It was also gathered from the study that $86.7 \%$ of the male farmers and $81.3 \%$ of the female farmers are Yoruba.

Table 2. Distribution of Age, Marital Status and Educational Level of Poultry Egg Farmers

\begin{tabular}{|c|c|c|c|c|c|c|}
\hline \multirow[t]{2}{*}{ Variable } & \multicolumn{2}{|c|}{ Male Household heads } & \multicolumn{2}{|c|}{ Female Household heads } & \multicolumn{2}{|c|}{ Aggregate } \\
\hline & Frequency & Percentage & Frequency & Percentage & Frequency & percentage \\
\hline \multicolumn{7}{|l|}{ Age } \\
\hline $31-40$ & 5 & 6.7 & 21 & 28.0 & 26 & 17.3 \\
\hline $41-50$ & 42 & 56.0 & 30 & 40.0 & 72 & 48.0 \\
\hline $51-60$ & 21 & 28.0 & 19 & 25.3 & 40 & 26.6 \\
\hline Total & 75 & 100 & 75 & 100 & 150 & 100 \\
\hline \multicolumn{7}{|c|}{ Marital status } \\
\hline Single & 3 & 4.0 & 7 & 9.3 & 10 & 6.7 \\
\hline Married & 71 & 94.7 & 64 & 85.4 & 135 & 90.0 \\
\hline \multicolumn{7}{|c|}{ Educational Level } \\
\hline Primary & 2 & 5.6 & 5 & 6.7 & 7 & 4.4 \\
\hline Secondary & 11 & 14.4 & 15 & 20.0 & 26 & 8.8 \\
\hline \multirow[t]{2}{*}{ Tertiary } & 62 & 80.5 & 55 & 73.3 & 117 & 86.8 \\
\hline & 75 & 100 & 75 & 100 & 150 & 100 \\
\hline
\end{tabular}

Source: Field Survey, 2013

The study further showed that majority $93.3 \%$ of male and $94.7 \%$ of female farmers have their household size falling between 1 and 8 members respectively. It is expected that the larger household size of both gender should translate to higher output and eventual profit due to available family labour on the farms.

Distribution of Respondents by Membership of Livestock Association, Access to social capital, Access to Extension Agent and Location of Poultry Farm : the result showed from Table 4 that majority as accounted for both male (93.5 percent) and female ( 86.7 percent) poultry egg farmers are members of a 
poultry farmer's association while 6.5 percent for male and 13.3 percent for female are not member of any poultry farmer's association. The result of the findings further revealed that 6.7 percent of male farmers had access to loan from government or any other source while none of the female farmers had access to loan. About 93.3 percent and 100.0 percent for male and female farmers respectively so sampled do not have access to loan. This revealed that despite their membership of associations most of the poultry egg farmers do not take advantage of the loan from either government or other organisation and this may be due to the high interest rate attached to such loans. In another vein it was further gathered from the findings that male and female farmers that had their farms located in the rural area are (58.7 percent) and (56.0 percent) respectively while 41.3 percent male farmers and 44.0 percent female farmers had their farms located in the urban areas. This might be due to the lot of litter generated from the farmers which may be unhygienic to people around the urban area.

Table 3. Distribution of Religion, Years of Experience, Ethnicity and Household Size of the Poultry Egg Farmers.

\begin{tabular}{|c|c|c|c|c|c|c|}
\hline \multirow[t]{2}{*}{ Variable } & \multicolumn{2}{|c|}{ Male Household heads } & \multicolumn{2}{|c|}{ Female Household heads } & \multicolumn{2}{|c|}{ Aggregate } \\
\hline & Frequency & Percentage & Frequency & Percentage & Frequency & percentage \\
\hline \multicolumn{7}{|l|}{ Religion } \\
\hline Christian & 39 & 52.0 & 52 & 69.3 & 91 & 60.7 \\
\hline Islam & 34 & 45.3 & 23 & 30.7 & 57 & 38.0 \\
\hline Traditional & 2 & 2.7 & 0 & 0 & 2 & 1.3 \\
\hline Total & 75 & 100 & 75 & 100 & 150 & 100 \\
\hline \multicolumn{7}{|c|}{ Experience (years) } \\
\hline Below9 & 60 & 80 & 64 & 85.3 & 124 & 78.0 \\
\hline $10-19$ & 12 & 16.0 & 11 & 14.7 & 23 & 14.5 \\
\hline $20-29$ & 2 & 2.7 & 0 & 0 & 2 & 1.2 \\
\hline Above29 & 1 & 1.3 & 0 & 0 & 1 & 6.3 \\
\hline Total & 75 & 100 & 75 & 100 & 150 & 100 \\
\hline \multicolumn{7}{|l|}{ Ethnicity } \\
\hline Yoruba & 65 & 86.7 & 61 & 81.3 & 126 & 84.0 \\
\hline Igbo & 7 & 9.3 & 14 & 18.7 & 21 & 14.0 \\
\hline Hausa & 3 & 4.0 & 0 & 0 & 3 & 2.0 \\
\hline Total & 75 & 100 & 75 & 100 & 150 & 100 \\
\hline \multicolumn{7}{|c|}{ Household size } \\
\hline $1-8$ & 70 & 93.3 & 71 & 94.7 & 141 & 88.7 \\
\hline $9-6$ & 4 & 5.4 & 4 & 5.3 & 8 & 5.0 \\
\hline Above16 & 1 & 1.3 & 0 & 0 & 1 & 6.3 \\
\hline Total & 75 & 100 & 75 & 100 & 150 & 100 \\
\hline
\end{tabular}

Source: Field Survey, 2013

Maximum Likelihood Estimate of the production Function of Male and Female Poultry Egg Farms : table 5 presents the Maximum Likelihood Estimate of the Cobb-Douglas production function of male and female poultry egg farms in Lagos State. The variance parameters for sigma-squared $\left(\delta^{2}\right)$ and gamma $(\gamma)$ for male and female farms were estimated at $0.113(P<0.10)$ and $0.328(P<0.01)$ and 0.899 $(P<0.01)$ and $0.979 \quad(P<0.01)$ respectively. The sigma-squared attests to the goodness-of-fit and correctness of the distributional form assumed for composite error term while the gamma indicates the systematic influences that are unexplained by production function and the dominant sources of random errors. This implies that about 89.9 percent and 97.9 percent of the variation in output of male and female poultry egg farms are due to differences in technical efficiency.

The parameter estimate obtained from the Maximum Likelihood Estimate (MLE) for male poultry egg farms revealed that labour inputs $\left(X_{2}\right)$ and cost of medication/drug $\left(X_{4}\right)$ have positive relationship with total output and significantly influence the output at both $1 \%(P<0.01)$ significant level. The result further revealed that farm size $\left(X_{1}\right)$ also has positive relationship with the farm output though not significant. This 
implies that they are efficiently allocated and utilized in the farm. However, feed supply $\left(X_{3}\right)$ has a negative relationship with output but though not significantly influence it. The negative sign of the feed supply showed that the total revenue from egg production decrease with increase in feed supply among the male farms. The result of the coefficient of MLE further revealed that labour input has the highest elasticity for male poultry egg farms in the study area. This means that male farms can be improved with increase in labour input.

Table 4. Distribution of Respondents According to Membership of Livestock Association, Access to Loan from Government or any Organisation, Access to Extension Agent and Location of Poultry Farm.

\begin{tabular}{|c|c|c|c|c|c|c|}
\hline \multirow{2}{*}{$\begin{array}{l}\text { Variable } \\
\text { Membership } \\
\text { livestock Associatio }\end{array}$} & \multicolumn{2}{|c|}{$\begin{array}{l}\text { Male Household heads } \\
\text { Frequency Percentage }\end{array}$} & \multicolumn{2}{|c|}{$\begin{array}{l}\text { Female Household heads } \\
\text { Frequency Percentage }\end{array}$} & \multicolumn{2}{|c|}{$\begin{array}{c}\text { Aggregate } \\
\text { Frequency percentage }\end{array}$} \\
\hline & & & & & & \\
\hline Member & 72 & 93.5 & 65 & 86.7 & 137 & 91.3 \\
\hline Non-member & 3 & 6.5 & 10 & 13.3 & 13 & 8.7 \\
\hline Total & 75 & 100 & 75 & 100 & 150 & 100 \\
\hline \multicolumn{7}{|l|}{ Access to loan } \\
\hline Beneficiary & 5 & 6.7 & - & - & 5 & 3.3 \\
\hline Non-Beneficiary & 70 & 93.3 & 75 & 100 & 145 & 96.7 \\
\hline Total & 75 & 100 & 75 & 100 & 150 & 100 \\
\hline \multicolumn{7}{|c|}{ Access to Ext. Agent } \\
\hline Below3 & 4 & 5.3 & 1 & 1.3 & 5 & 3.4 \\
\hline $4-6$ & 26 & 34.6 & 44 & 57.8 & 70 & 46.6 \\
\hline $7-9$ & 19 & 25.3 & 5 & 8.4 & 24 & 16.0 \\
\hline Above10 & 26 & 34.8 & 25 & 32.5 & 51 & 34.0 \\
\hline $\begin{array}{l}\text { Total } \\
\text { Location of Pou } \\
\text { farm }\end{array}$ & 75 & 100 & 75 & 100 & 150 & 100 \\
\hline Rural & 44 & 58.7 & 42 & 56.0 & 64 & 42.7 \\
\hline Urban & 31 & 41.3 & 33 & 44.0 & 86 & 57.3 \\
\hline Total & 75 & 100 & 75 & 100 & 150 & 100 \\
\hline
\end{tabular}

Source: Field Survey, 2013

The years of experience, level of education, marital status, access to extension service and access to credit to farm inefficiency model was also examined. The magnitude of the coefficients of these variables has important policy implication as positive sign implies negative effect on efficiency while negative sign signifies a positive effect on efficiency.

The gamma value of 0.89 which is significant at $1 \%$ level of significance confirms the presence of technical inefficiency among male farmers. This indicates that $89 \%$ variation in output of male farms in the study area would be attributed to technical inefficiency while $11 \%$ would be due to random effect. The result of the inefficiency model showed that Educational level $\left(Z_{2}\right)$ negatively influence inefficiency of the male farmers and not significantly influence it. This reveals that male poultry egg farmers in the study area tends to be more efficient technically when there are increase in educational level of the male poultry farmers.

Furthermore, the Stochastic Frontier Model for female poultry farmers' revealed that farm size $\left(X_{1}\right)$ and labour input $\left(X_{2}\right)$ which is significant at $1 \%(P<0.01)$ and Cost of Medication/Drugs $\left(X_{4}\right)$ having $10 \%$ $(P<0.10)$ level of significance with positive relationship with output. However, the coefficients of Feed 
supply $\left(X_{3}\right)$ which is less than unity have negative relationship with output of female poultry farmers but also significantly influence their output at $1 \%$ level of significance. This showed that these variables exert significant influence on farm output of these categories of farmers. The result further revealed that in this production system Labour input $\left(\mathrm{X}_{2}\right)$ also has the highest elasticity which also implies that productivity of the female poultry farmer's increase with increase in the labour input. The gamma value of 0.97 indicates that $97 \%$ variation in output of the female poultry egg farmer would be attributed to technical inefficiency effects alone while only $3 \%$ would be attributed to random effects.

Table 5. The Stochastic Frontier Production Result for Male and Female Poultry Egg Farms

\begin{tabular}{|c|c|c|c|c|}
\hline Variable & $\begin{array}{c}\text { Regression } \\
\text { Coefficients for } \\
\text { Male farms }\end{array}$ & T-Value & $\begin{array}{l}\text { Regression } \\
\text { Coefficients for } \\
\text { Female farms }\end{array}$ & T-value \\
\hline \multicolumn{5}{|l|}{ Production Function } \\
\hline Constant & $\begin{array}{c}-4.11^{* * *} \\
(1.35)\end{array}$ & -3.05 & $\begin{array}{l}-0.91 \\
(0.72)\end{array}$ & -1.19 \\
\hline Farm size $\left(X_{1}\right)$ & $\begin{array}{c}0.040 \\
(0.058)\end{array}$ & 0.64 & $\begin{array}{l}0.142 * * * \\
(0.03)\end{array}$ & 4.24 \\
\hline Labour input $\left(X_{2}\right)$ & $\begin{array}{l}1.17^{* * *} \\
(0.12)\end{array}$ & 9.97 & $\begin{array}{c}0.87^{* * *} \\
(0.02)\end{array}$ & 43.49 \\
\hline Feed supply $\left(X_{3}\right)$ & $\begin{array}{l}-0.078 \\
(0.053)\end{array}$ & -1.48 & $\begin{array}{c}-0.08 \\
(0.0086)\end{array}$ & -9.82 \\
\hline $\begin{array}{l}\text { Cost of } \\
\text { Medication/Drugs }\left(\mathrm{X}_{4}\right) \\
\text { Inefficiency Model }\end{array}$ & $\begin{array}{l}0.087^{* * *} \\
(0.034)\end{array}$ & 2.55 & $\begin{array}{c}0.028 \\
(0.017)\end{array}$ & 1.67 \\
\hline Constant & $\begin{array}{c}0.24 \\
(0.28)\end{array}$ & 0.64 & $\begin{array}{l}-4.91 \\
(3.19)\end{array}$ & -1.54 \\
\hline Years of Experience $\left(Z_{1}\right)$ & $\begin{array}{l}-0.01 \\
(0.01)\end{array}$ & -1.02 & $\begin{array}{l}-0.023^{*} \\
(0.012)\end{array}$ & -1.88 \\
\hline Educational level $\left(Z_{2}\right)$ & $\begin{array}{l}-0.041 \\
(0.29)\end{array}$ & -0.14 & $\begin{array}{l}0.226 \\
(1.53)\end{array}$ & 1.46 \\
\hline Marital status $\left(Z_{3}\right)$ & $\begin{array}{c}0.030 \\
(0.022)\end{array}$ & 1.35 & $\begin{array}{l}0.165^{* *} \\
(0.075)\end{array}$ & 2.18 \\
\hline $\begin{array}{l}\text { Access to Extension } \\
\text { service }\left(Z_{4}\right)\end{array}$ & $\begin{array}{c}-0.79^{* * *} \\
(0.15)\end{array}$ & -5.19 & $\begin{array}{c}0.00 \\
(1.00)\end{array}$ & 0.00 \\
\hline Access to credit $\left(Z_{5}\right)$ & $\begin{array}{l}-0.0038 \\
(0.0067)\end{array}$ & -0.56 & $\begin{array}{l}-0.01^{* * *} \\
(0.0027)\end{array}$ & -3.76 \\
\hline Diagnostic Statistics & & & & \\
\hline Sigma-squared $\left(\delta^{2}\right)$ & $\begin{array}{c}0.1132^{* * *} \\
(0.0257)\end{array}$ & 4.39 & $\begin{array}{l}0.328^{*} \\
(0.194)\end{array}$ & 1.69 \\
\hline Gamma $(\gamma)$ & $\begin{array}{c}0.99^{* * *} \\
(0.00209)\end{array}$ & 477.34 & $\begin{array}{c}0.97^{* * *} \\
(0.00501)\end{array}$ & 199.42 \\
\hline
\end{tabular}

${ }^{* * *}$ implies significanceat 1 percent, ${ }^{* *}$ implies significanceat 5 percent, ${ }^{*}$ implies significanceat 10 percent Figures in parenthesis are the standard errors

Source: Field Survey, 2013

Efficiency Analysis of Poultry Egg Farmers

Technical Efficiency of Male and Female Poultry Egg Farms : the frequency distribution of the technical efficiency estimates of Male and Female poultry egg farms is as presented in Table 6. Majority (34.7 percent) of the Male farms have their technical efficiency between 0.40 and $0.49,14.7$ percent have their technical efficiency between 0.50 and 0.59 while 4.0 percent of the farmers have their technical efficiency greater than 0.90 . Moreso, 6.7 percent of the farmers also has their technical efficiency to be less than 0.29 . The mean technical efficiency of male poultry egg farms was estimated to be 0.5352 . On 
the other hand, the technical efficiency of female farms has majority of 28.0 percent of the farms between 0.70 and 0.79 with 2.7 percent having their technical efficiency greater than 0.90 . This gave a mean technical efficiency of 0.6065 for the female poultry egg farms. The mean output efficiency of 53 percent and 61 percent showed that there is potential to increase output by 47 percent and 39 percent by male and female poultry egg farms respectively under the present technology.

Economic Efficiency Estimates of Male and Female Poultry Egg Farms : the frequency distribution of the economic efficiency of the poultry egg farms which was estimated as the product of technical and allocative, i.e $E E=\mathrm{TE} \times$ AEis presented in Table 8 . The result of the data analysis revealed that majority (81.4 percent) of male poultry egg farms had their economic efficiency to be between 0.40 and 1.00 with mean efficiency of 0.5317 . In the same vein, majority (84 percent) of female poultry egg farms have their economic efficiency to be between 0.40 and 1.00. Moreso, 14.7 percent female farms have their economic efficiency to be between 0.30 and 0.39 with mean efficiency of 0.6026 . The mean economic efficiency for both male and female poultry egg farms implies that there is room for improvement by 46.83 percent and 39.74 percent respectively.

Table 6. Distribution of Technical and Economic Efficiency of Male and Female Poultry Egg Farmers

\begin{tabular}{|c|c|c|c|c|c|c|}
\hline $\mathrm{Clacs}$ & $\begin{array}{l}\text { Male farms } \\
\text { Frequency }\end{array}$ & & $\begin{array}{l}\text { Female } \\
\text { farms }\end{array}$ & & Aggregate & \\
\hline Class & & Percentage & & Percentage & Frequency & Percentage \\
\hline \multicolumn{7}{|l|}{ Technical } \\
\hline \multicolumn{7}{|l|}{ Efficiency } \\
\hline$\leq 0.29$ & 5 & 6.7 & 1 & 1.3 & 6 & 4.0 \\
\hline $0.30-0.39$ & 9 & 12.0 & 11 & 14.7 & 20 & 13.3 \\
\hline $0.40-0.49$ & 26 & 34.7 & 11 & 14.7 & 37 & 24.7 \\
\hline $0.50-0.59$ & 11 & 14.7 & 13 & 17.3 & 24 & 16.0 \\
\hline 0.60-0.69 & 8 & 10.7 & 8 & 10.7 & 16 & 10.7 \\
\hline 0.70-0.79 & 7 & 9.3 & 21 & 28.0 & 28 & 18.7 \\
\hline $0.80-0.89$ & 6 & 8.0 & 8 & 10.7 & 14 & 9.3 \\
\hline$\geq 0.90$ & 3 & 4.0 & 2 & 2.7 & 5 & 3.3 \\
\hline Total & 75 & 100 & 75 & 100 & 150 & 100 \\
\hline Mean & 0.5352 & & 0.6065 & & & \\
\hline \multicolumn{7}{|l|}{ Economic } \\
\hline \multicolumn{7}{|l|}{ Efficiency } \\
\hline$\leq 0.29$ & 5 & 6.7 & 1 & 1.3 & 6 & 4.0 \\
\hline $0.30-0.39$ & 9 & 12.0 & 11 & 14.7 & 20 & 13.3 \\
\hline 0.40-0.49 & 26 & 34.7 & 11 & 14.7 & 37 & 24.7 \\
\hline $0.50-0.59$ & 11 & 14.7 & 13 & 17.3 & 24 & 16.0 \\
\hline $0.60-0.69$ & 8 & 10.7 & 8 & 10.7 & 16 & 10.7 \\
\hline 0.70-0.79 & 7 & 9.3 & 21 & 28.0 & 28 & 18.7 \\
\hline $0.80-0.89$ & 6 & 8.0 & 10 & 13.3 & 16 & 10.7 \\
\hline$\geq 0.90$ & 3 & 4.0 & 0 & 0 & 3 & 2.0 \\
\hline Total & 75 & 100 & 75 & 100 & 150 & 100 \\
\hline Mean & 0.5317 & & 0.6026 & & & \\
\hline
\end{tabular}

Source: Field Survey Data, 2013.

Test of Difference of Mean Economic Efficiency between Male and Female Poultry Egg Farmers : the test of difference of mean economic efficiency between male and female was achieved using t-test of mean difference. It was based on the hypothesis that there is no significant difference between the economic efficiency of male and female farmers. The result of the t-test showed that there is significant difference $(P<0.05)$ between the economic efficiency of male and female poultry egg farmers (Table 7$)$.

The findings showed that 62.7 percent and 73.3 percent of male and female poultry egg farmers are aged below 50 years (Table 2 ). This implies that majority of the farmers are in their active age and are 
therefore expected to influence the efficiency of the farm units sampled. The age distribution of the farmers informs their skill, ability and willingness to adopt new innovations and technologies which can be used to transform the poultry industry in the study area.

Table 7. Test of Difference of Mean Economic Efficiency between Male and female farms.

\begin{tabular}{lllllll}
\hline Test & $\begin{array}{l}\text { Mean } \\
\text { Efficiency }\end{array}$ & $\begin{array}{l}\text { Standard } \\
\text { Deviation }\end{array}$ & $\mathrm{N}$ & Df & T-Value & Decision \\
\hline Economic Efficiency & & & & & & Reject $\mathrm{H}_{\mathrm{o}}$ \\
Male & 0.5317 & 0.17906 & 75 & 148 & $-2.478^{* *}$ & Re6 \\
Female & 0.6026 & 0.17103 & 75 & & & \\
\hline
\end{tabular}

Source: Field Survey Data, 2013. ${ }^{* *}$ implies significanceat 5 percent

The result of the Maximum Likelihood Estimate of Stochastic Frontier Analysis (SFA) revealed the parameter estimate of stochastic production function of male poultry egg farms showed that labour input $\left(X_{2}\right)$ and cost of medications $\left(X_{4}\right)$ exert positive influence on total output and significantly influence the output at $1 \%(P<0.01)$ and $5 \%(P<0.05)$ respectively. The result further showed that Cost of feeds $\left(X_{3}\right)$ shows negative relationship with the farm output and also stock of birds $\left(X_{1}\right)$ have positive relationship with the farm output but do not significantly influence the value of output. In the same vein the parameter estimate for female poultry egg farms revealed that Stock of birds $\left(X_{1}\right)$, labour input $\left(X_{2}\right)$, and feed $\operatorname{cost}\left(X_{3}\right)$, are all significant at $1 \%(P<0.01)$ and cost of medication $\left(X_{5}\right)$ has a significance of $10 \%$ $(P<0.10)$ also the feed $\operatorname{cost}\left(X_{3}\right)$ is having negative relationship with output. The finding further revealed that male poultry egg farms are operating at stage $1(E>1)$ of production which is at increasing return to scale while female poultry egg farms is operating at stage $2(E<1)$ of production and at a decreasing return to scale.

The result of the Stochastic Cost Function revealed that wage rate of labour $(P<0.05)$, Price of feed $(P<0.01)$ and capital input $(P<0.01)$, for male poultry egg farms conform with the a prior expectation with positive, while Price of feed $(P<0.01)$, Price of drug $(P<0.01)$ and Price of initial stock $(P<0.01)$ also conform with the a prior expectation in case of female poultry egg farms. The result revealed that in case of female poultry egg farms, price of feed, price of initial stock of birds and price of drugs will increase the total cost of production while wage rate of labour, price of feed, price of drugs exert significant influence on the total cost of production in the case of male poultry egg farms.

The result of the study revealed that the inefficiency model showed that gender $\left(Z_{5}\right)$ negatively influence the inefficiency and was significant at $(P<0.01)$ for technical efficiency. This shows that males are more technically efficient than their female counterpart.

Male poultry egg farmers (majority had tertiary education) are more advanced in terms of education than female poultry egg farmers. It is also clear from membership to livestock association; the percentage result of male poultry egg farms that are members (93.5\%) is higher compared to that of their female (86.7\%) counterparts in the study area. Thus, the present study revealed that male poultry farmers are more likely to gain access to information on technical know-how than female farmers. Therefore female farmers should be sensitized on the membership of livestock association. Based on findings of this study, the following policy recommendations were advanced to positively bring about improvement in poultry egg production. More effort should be intensified on the part of extension agents in educating poultry egg farmers to improve their efficiencies in egg production. Poultry egg farmers in collaboration with the Poultry Association should be encouraged to participate in educative programmes such as seminars, workshops and symposiums on various current practices in poultry egg production in order to increase production. Female poultry egg farmers should make concerted efforts to increase their stock size as this will go a long way to improve the efficiency of the farmers. The governmental institutions also should encourage women in poultry agriculture, by mandating farmers to employ some certain percentage of ladies in their farms also incentive and support should be given to females to encourage them for food production.

\} 
Sustainability, Agri, Food and Environmental Research 4(1), 2016: 50-60

ISSN: 0719-3726

\section{References}

Akanle, O., \& O. Olutayo, 2011. Kinship construction variability among Nigerian international migrants: The context of contemporary Diaspora. Human Affairs, 21: 470-480.

Apantaku, S.O., 2006. Analysis of Participation of Farmers in Participatory Poultry Production Research in Lagos State - Nigeria. Livestock Research for Rural Development, 18: 1-4.

Bamiro, O. M., D.O.A. Phillip, \& S. Momoh, 2006. Vertical Integration and Technical Efficiency in Poultry (Egg) Industry in Ogun and Oyo State, Nigeria" International Journal of Poultry Science 5: 1154-1171.

C.B.N. (2001): Economic and Financial Review 36 (1): 202-235

Chukwuji, C.O., E.I. Odjuvwuederhie, D.O. O'raye, \& W.J. Oyaide, 2006. A Quantitative Determination of Allocative Effi ciency in Broiler Production in Delta State, Nigeria. Agriculturae Conspectus Scientificus, 71: 21-26.

Da Silva, C.A., 2009. Agro-industries for development. CABI.

Deller, S. C., 2014. Contribution of Agriculture to the Wisconsin Economy: Updated for 2012.

IFAD, 2007 Women livestock managers in the third world: a focus on technical. Retrieved from http://www.ifad.org/gender/thematic/livestock/live_toc.htm

Iyi, O.A., I.O. Adesiyan, \& R.A. Ayoade, 2008. Constraints to utilization of poultry production technologies among farmers in Oyo State, Nigeria. Journal of Human Ecology 24: 305-309.

Mbanelo, M., 2002. Women: A potent labour force in grassroots development. A paper Presented at the National Conference on Development at the Grassroots in the 1990s, 16-7 May, Hotel Presidential, Enugu, Nigeria. 23: 35-42.

Mukhtar, U., 2012. Economic Analysis of Poultry-Egg Production in Bauchi Local Government Area, Bauchi State, Nigeria. Ahmadu Bello University, Zaria.

Nweke, A.N., 2003 Role of women in agricultural production in Awka education zone of Anambra State: Implication for adult education in agriculture. Unpublished M.Ed Thesis. University of NigeriaNsukka, Nigeria. 17: 36-45

Odetola, T., \& C. Etumnu, 2013. Contribution of Agriculture to Economic Growth in Nigeria. The 18th Annual Conference of the African Econometric Society (AES) Accra, Ghana at the session organized by the Association for the Advancement of African Women Economists (AAAWE), 22nd and 23rd July, 2013.

Ogungbeni, J., W. Ogungbo, \& O. Adeleke, 2013. Agricultural information needs of farmers in Lagos State, Nigeria. International Journal of Agricultural Science Research, 2: 116-123.

Ojo, S.O. 2003. Productivity and Technical Efficiency of Poultry Egg Production in Nigeria. International Journal of Poultry Science 2: 459-464.

Okoh, S. O., S.A. Rahman, \& H.I. Ibrahim, 2010. Gender participation in commercial poultry production in Karu and Lafia Areas, Nasarawa State, Nigeria. Livestock Research for Rural Development, 22(9).

Paddy, A., 2001. Poultry Business Heads for Doom. Nigeria Agricultural Magazine, Nov/Dec 130 Periurban poultry production. 4: 130-145

Rahman, S.A. \& J.F. Alamu, 2003. Estimating the level of Women's Interest in Agriculture: An Application of Logit Regression Model. The Nigerian Journal of Scientific Research. 4: 45-49.

Rahman, S.A., H. Ibrahim, \& H. Ibrahim, 2007. Socio-Economic Study of Gender Role in farm production in Nasarawa State of Nigeria. Asia Pacific Journal of Rural Development 17: 57-58.

Saito, K.A. \& D. Spurling, 2000- Developing Agricultural Training for Women, 2000, World Bank, Washington, D.C. $119 \mathrm{pp}$

Tijani, B.A., H. Tijjani, A., \& A. Tijjani, 2015. Resource Use Efficiency In Poultry Egg Production In Maiduguri and Environs Of Borno State, Nigeria. Journal of Economics and Sustainable Development, 6: 341-356. 